troen. Et spørgsmål, jeg som så mange andre spørgsmål efter læsningen af denne righoldige bog lades tilbage med.

Steen Klitgard Povlsen

\section{Europæisk idehistorie} Hans-Jorgen Schan₹: Europaisk idebistorie. Historie, samfund, eksistens, Host og son 2002, 237 sider, 350 kr.

To professorer ved Aarhus Universitet udgav i det forgangne århundrede hver sin vældig gode oversigt over filosofiens historie, Justus Hartnacks Filosofiske problemer (1956) og Johannes Sløks De europaiske ideers historie (1963); den første beregnet som lærebog ved filosofikum, en disciplin alle universitetsstuderende dengang skulle til eksamen i, den anden for gymnasiet, hvorfor gymnasierektor Erik Lund og fysiklærer Mogens Pihl stod som medforfattere, skønt Sløk havde skrevet næsten det hele. Ingen af disse to bøger ville være filosofihistorier i traditionel forstand. Hartnack ville slet ikke skrive historie. For ham havde filosofi og historie intet med hinanden at gøre. Hans bog var, som titlen angiver, en bog om de vigtigste filosofiske problemer, som er blevet "opdaget" og diskuteret $\mathrm{i}$ historiens løb. Han tog dem op i kronologisk rækkefølge, men kunne ifølge sit eget program udmærket have behandlet dem i en anden, mere systematisk rækkefølge, og den historiske kontekst, de opstod $i$, interesserede ham ikke. Hvad der interesserede ham, var problemerne og forsøgene på at løse dem. Var der tale om pseudoproblemer, som skyldtes sprogligt eller filosofisk roderi, eller æate filosofiske problemer, som stadig kalder på løsningsforsøg. Bogen var, kan man sige, en kronologisk ordnet eksempelsamling, hvor studenterne kunne stifte bekendtskab med forskellige måder at formulere filosofiske problemer og argumentere for deres løsning på. Sløks bog derimod ville gerne være en historie, men en idehistorie, ikke en filosofihistorie. Formålet var tilsyneladende ikke at gennemgå kongerækken af filosoffer og deres forfatterskaber, men at præsentere de vigtigste ideer, som i historiens løb er dukket op i Europa, ikke kun inden for filosofien, men inden for teologi, kunst, politik m.v. Overskrifterne angiver disse ideer og nævner ingen filosofnavne. Ud over Platon figurerer der ikke et eneste navn i Sløks overskrifter og indholdsfortegnelse.

Schanz tegnede for nogle år siden i essaysamlingen Det historiske (1996) et rids af filosofihistoriernes historie. Han skelnede mellem, hvad han kaldte den "ortodokse" eller traditionelle filosofihistorie, som udvikledes i det 19. århundrede, og to nye tilgange, som opstod i opposition hertil i årene omkring 1900: en analytisk og en "geistesgeschichtlich". Den første - eksemplificeret med Bertrand Rus- 
sels Filosofiske problemer - distancerede sig fra filosofihistorien som noget ret uvæsentligt for den aktuelle filosofiske videnskab, ret beset kun en eksempelsamling eller mere eller mindre eksotisk forhistorie, som kunne undværes, ligesom naturvidenskaberne udmærket kan undvære deres forhistorie. Den anden - eksemplificeret med Windelbands Lebrbuch der Geschichte der Philosopbie (1892) - havde derimod ikke kun filosofihistorien med sig, men hele åndshistorien, den ville være en "Geschichte der Probleme under der Begriffe", anskuet i deres historiske kontekst. Schanz placerer Hartnack og Sløk i hver sin af disse to traditioner og yder sine to århusianske forgængere fuld anerkendelse. Men han gør det alene med det argument, at de ikke programmatisk forkastede den tilgang, han selv sværger til, nemlig den "ortodokse" eller traditionelle filosofihistorie, som holder sig så tæt til kongerækken, dens forfatterskaber og enkelte tekster som vel muligt, og som har vist og fortsat viser sin levedygtighed, uanset hvor mange gange den er blevet dømt til døden af Richard Rorty og andre.

Er det en sådan ortodoks filosofihistorie, han nu har skrevet? Nej, det er det ikke. Som titlen angiver, skal det være en europæisk idehistorie. Schanz har rigtignok hele kongerækken med i sine overskrifter, men der figurerer også en hel del ideer, og der står mange andre navne end filosoffers, også nede i teksten: Ricardo,
Leopold von Ranke, Spengler, Hitler, Levi-Strauss og mange flere. En ortodoks filosofihistorie ville have koncentreret sig mere om traditionelle filosofiske discipliner som metafysik, etik og erkendelsesteori. Hos Schanz er navnlig den sidste lavt prioriteret. Han angiver i stedet tre andre områder som dem, bogen skal handle om, nemlig historie, samfund og eksistens (Sløk havde "verden, mennesket og samfundet"). De træder rigtignok først tydeligt frem i bogens anden halvdel, da filosofien fra oplysningstiden og frem spaltes $i$ stadigt flere videnskaber, historie, økonomi, sociologi, psykologi, sprogteori osv., og Schanz må følge den teoretiske udvikling på sine tre områder et stykke på vej. Naturvidenskaberne kommer han ikke meget ind på. Hverken Einstein eller Bohr er nævnt. Schanz har jo ikke som Sløk "verden" med blandt sine foretrukne områder $o g$ har derfor heller ikke haft nødig at hente en fagmand ind til hjælp på dette felt. Til gengæld går han langt grundigere til værks med den økonomiske og sociologiske teoris historie, end Sløk gjorde, og med den historiske fagtradition, hvad man som historiker naturligvis er glad for.

Men man spørger sig: Hvad er det egentlig for et fag, dette idehistorie, som altså ikke vil være filosofihistorie og slet ikke filosofi i Hartnacks forstand, men som vil være bredere og omfatte religion, kunst, historie og meget mere? Både Schanz og Sløk gør meget ud af teologi og kristen- 
dom, og begge er de på lejlighedsvise besøg i kunstens verden, Sløk bl.a. hos Michelangelo og Picasso, Schanz hos Thomas Mann og Stefan Zweig, og som nævnt også i økonomiens, sociologiens, historiefagets, fysikkens og mange andre verdener. Mig forekommer det, at disse idehistorikere dog først og fremmest er filosoffer. Rygraden i deres bøger er og bliver filosofihistorien, hos Schanz klart og tydeligt og mere bevidst end hos Sløk, der holdt sine overskrifter fri for filosofnavne - hvad der jo egentlig var bluff, for navnene kunne lynhurtigt føjes til med blyant. Hos dem begge er den filosofihistoriske kanon hovedsagen. Og det en udpræget kontinental version af samme kanon. Efter Hobbes og Locke forekommer angelsaksiske navne yderst sjældent. Kun når tyskere og østrigere drager i landflygtighed, bevæger vi os en stund bort fra det europæiske kontinent. Og synsvinklen er overalt filosofisk, især hos Schanz. Vi har at gøre med en filosof, der taler om historiefilosofi, socialfilosofi og eksistensfilosofi, når han tager hvert af sine tre områder for sig. Dette er påfaldende, i hvert fald for en historiker, der jo ikke mener, at historie er noget, man filosoferer over, men noget, man undersøger på helt anderledes konkrete måder. Et spørgsmål, som Schanz nævner flere gange, lyder: har historien en mening?

Jeg har aldrig hørt eller læst om nogen historiker - bortset fra enkelte originaler i en mørk hegeliansk fortid
- som stillede sig et sådant spørgsmål. I gængse fremstillinger af historieskrivningens historie forekommer undertiden små parentetiske afsnit om noget, der kaldes historiefilosofi, hvor Hegel, Spengler, Toynbee og måske et par stykker til er nævnt, men ikke som noget, der på nogen måde tages alvorligt. Ingen af de herrer indgår i den historiografiske kanon. Schanz er ikke selv historiefilosof, men han er filosof. Det må vel være derfor, han giver historiefilosofien så uforholdsmæssig stor en plads i sin korte fremstilling.

Personligt finder jeg filosofihistoriens store navne dybt interessante, både de kontinentale og dem på den anden side af det store vand, og jeg har under mit korte idehistoriske bifagsstudium og siden haft lejlighed til beskæftige mig lidt grundigere med nogle af dem. Men jeg spørger mig selv: var de og deres skrifter så vigtige i den store historiske sammenhæng, herunder den idehistoriske? Lockes Two Treatises fik en vis status som officiel engelsk ideologi efter revolutionen 1688 og spillede vel en vis rolle for den franske oplysningsfilosofi og udformningen af den amerikanske uafhængighedserklæring - skønt de $\mathrm{i}$ alle disse sammenhænge kun var dele af et langt større landskab - men hvad med Hobbes, og hvad med vores egen Søren Kierkegaard? Hvad skal Kierkegaard i så kort en sammenfatning af idehistoriens store landskaber? Var f.eks. ikke H.C.Andersens eventyr vigtigere, el- 
ler hele det mægtige materiale af folkelige fortællinger, som hans eventyr tog udgangspunkt i, og som foreligger i store mængder fra hele Europa? Hvilken rolle spillede Hegel uden for Berlin, visse andre tyske universitetsbyer og i korte perioder København og Napoli, sammenlignet med f.eks. Napoleon? Var ikke myten om den lille artilleriofficer, der blev kejser, den grimme xlling, der blev til en svane, avisdrengen, der blev millionær, eller alle de andre karrierefortællinger, som fortsat plager samfundet, herunder det universitet, Schanz er en del af, langt vigtigere end Hegel, Kierkegaard, Nietzsche og et helt bundt andre filosoffer tilsammen? Og hvad med drømmen om den store kærlighed? Hvad med den kæmpemæssige skov af romantiske fortællinger og sange, som væltede ud i offentligheden fra midten af det 19. århundrede og satte sig næsten lige så fast $\mathrm{i}$ folks hoveder, som drømmen om den himmelske salighed hidtil havde gjort det? Hvor bliver fortællingerne af? De gamle fortællinger om skabelsen, syndefaldet og Jesus blev jo ikke kun afløst af systematisk tænkning og analyserende videnskab. De blev først og fremmest afløst af andre fortællinger, f.eks. Gibbons, Rousseaus, Burkhardts, Thomas Manns, Spenglers og tusind andres efterårsfortælling om det gamle, dekadente Europa og dets forfald og den hermed nært beslægtede forårsfortælling om den friske livskraft hos en Hitler, Stalin eller Donald Rums- feld. Hvad med fortællingen om det tabte land, Palæstina, Kosovo eller Sydslesvig, som man med folkets urgamle ret vil vinde tilbage, eller fortællingen om den stærke retfærdige helt, der sejrede over ondskaben $i$ en by i Texas, Vietnam eller Irak? Hører disse fortællinger ikke med til idehistorien? I mindst ligeså høj grad som Heidegger og den Husserl, som et par anmeldere gudhjælpemig har efterlyst? Jeg spørger til filosoffernes såkaldte virkningshistorie, ikke kun i senere filosoffers hoveder, herunder Schanz', men i den brede befolknings, ja bare den brede elites. Jeg spørger: er europæisk idehistorie ikke andet end filosofihistoriens kongerække suppleret med lidt kirkehistorie og et par enkelte andre teorihistoriske kongerækker?

Og jeg spørger til "materialhistorien", som det hed engang på Institut for Idehistorie, dengang alle sad ved Schanz' fødder og lærte om Marx. For øvrigt et navn, der fortjener en plads i en hvilken som helst idehistorie, også den jeg efterlyser, en tænker, som - hvad enten man kan lide det eller ej - virkelig fik sig en "virkningshistorie" uden for filosofihistorien, en socialistisk revolutionær og økonom, som i øvrigt ville afskaffe filosofien og alt dens væsen, herunder både filosofihistorien og historiefilosofien. Schanz udnævner ham minsandten til historiefilosof, selvom Marx udtrykkeligt tog afstand fra enhver universel historieteori. Den vulgære version af den materialistiske historieopfattelse, 
som to små tvivlsomme tekster, Det kommunistiske manifest og et lille forord fra 1859, gav anledning til, og som fik den allerstørste betydning i eftertiden, kan rigtignok i f.eks. Stalins udgave udmærket betegnes som historiefilosofi, men at Schanz uden forbehold kan fremholde denne vulgære version som Marx's egen opfattelse, er mig ubegribeligt. Det lader til, at filosoffen Schanz på det nærmeste har afskaffet den Marx, der i sin tid afskaffede filosofien. Også hans økonomiske teori. Grænsenytteteoriens opgør med arbejdsværditeorien tages uden videre for pålydende. Man undres og græmmes.

Nå, tilbage til "materialhistorien". Den er heldigvis ikke ganske afskaffet. Handelen i det græske område tilkendes en vis betydning som baggrund for filosofiens opkomst. Siden har Schanz ikke meget med om den økonomiske baggrund, før vi når frem til reformationen og navnlig 1600-tallets videnskabelige revolution, hvor kapitalismen introduceres. Lidt for tidligt, synes det mig for resten. Kapitalismens egentlige gennembrud hører vel hjemme i det 19. århundrede, hvis det da ikke er pengekapital og handelskapitalisme vi taler om. Men overalt er den økonomiske, sociale og politiske baggrund kun tegnet $i$ grove rids af samme type, som Erik Lund og Sløk kunne lave. Vi får ingen nærmere udredning af sammenhængene mellem markedsøkonomien og f.eks. ideerne om frihed og lighed. Schanz har afskaffet ideologikritikken og den "mistankens hermeneutik", som frankfurterne stod for. Jeg græmmes igen og spørger: Vel bør ingen ide, intet udsagn alene dømmes på sin oprindelse eller samfundsmæssige funktion - hverken gyldigheden eller sandhedsværdien afhænger jo heraf - og vel skal enhver tekst læses på sine egne præmisser, empatisk og åbent, i sammenhæng med alle tænkelige kontekster, før man spørger, om der bevidst eller ubevidst stikker noget under: et rollespil, som pengene har genereret, en klasseinteresse, et ressentiment af den ene eller anden type, eller hvad ved jeg. Men er det slet ikke længere tilladt at stille sådanne spørgsmål?

Schanz' nye bog er ikke kun en filosofihistorie. Den er en filosofihistorie med tilbehør. Ligesom Sløks. Tilbehøret er bare lidt forskelligt. Som sådan er det en god bog. Den kan undertiden virke lidt sammentrængt og opremsende. Schanz har kun bevilget sig sølle 237 sider mod Sløks 375. Måske skulle han have givet sig selv lidt mere plads. Enkelte oplysninger om noget vigtigt, som skulle med, men som der kun lige er tid til at nævne, hænger i luften og bliver svære at forstå. Det samme gælder enkelte længere udredninger, hvor for meget forudsættes bekendt, og Schanz er mere optaget af sin egen tolkning og sammenfatning end af at fremlægge stoffet for den forudsætningsløse læser. Han har sin styrke i polemikken og den tilspidsede pointe, fornemmer man, mere end $\mathrm{i}$ 
den grundige fremlæggelse. Men gennemgående er bogen usædvanlig klart skrevet. Undertiden også levende og engageret. I omtalen af Marx er der rigtignok ikke mange oplivende momenter, hverken indholdsmæssigt eller sprogligt, men hvor det gælder Kierkegaard, læser man f.eks. følgende: "Gud er ikke fornuft, mennesket ikke modernitet, livet er ikke en fremtidsgesiæft og døden ikke et trafikuheld på civilisationens motorvej”. Schanz ejer vel ikke Sløks sprogligt litterære mesterskab. Over for forgængerens større og rigere billeder er hans fremstilling at ligne ved stivere, fattigere træsnit. Men træsnit kan være at foretrække, når de klart og uden for mange nuancer trækker det væsentlige frem.

Det fremgår ikke som hos Hartnack og Sløk, hvem bogen er skrevet for. Skal den være et tov mellem tekstknuderne i de idehistoriestuderendes introduktion til filosofihistorien, er den beregnet for det nye "studium generale", som man planlægger for så vidt muligt alle universitetsstuderende, og som Schanz vist nok gerne så som en slags genindførelse af filosofikum, er det en gymnasielærebog som Sløks, eller er det en oversigt beregnet for lægmænd, f.eks. historikere, der gerne vil vide lidt mere om filosofi? Hartnacks bog tjente sit formål på udmærket vis, Sløks ikke. Den var for svær for gymnasieelever. Det tror jeg også, Schanz' bog er. Men som oversigtsværk for folk, der ved lidt i forvejen, og trænger til en sammenfatning, er det en udmærket traditionel filosofi-, undskyld idehistorie.

\section{Steen Busck}

\section{Det er svært at være in- tellektuel}

Dorthe Jorgensen, Viden og visdom. Sporgsmàlet om de intellektuelle, Det lille forlag, Frederiksberg 2002, 125 sider, $175 \mathrm{kr}$.

Forfatteren til Viden og visdom. Sporgsmålet om de intellektuelle følte sig givetvis personligt ramt, da statsminister Anders Fogh Rasmussen i sin nytårstale ved overgangen til 2002 langede ud efter eksperter og smagsdommere. Ramt, dels fordi Dorthe Jørgensen $i$ sin egen forståelse af den intellektuelle var en af dem, der sigtedes til, dels fordi statsministeren gav endnu et eksempel på det 'dem og os', der ifølge Jørgensen længe har præget debatten i Danmark.

Statsministeren placerer de intellektuelle over for folket $i$ en enten-eller figur, som vidner om en antiintellektualistisk tankegang — en tankegang, som Viden og visdom sætter sig for at analysere, problematisere og give et nuanceret modsvar på. Brikker i dette spil er en række prisværdige og tankevækkende idéhistoriske refleksioner over viden og visdom, psykologi og terapi, det æstetiske, sandheden, den ulykkelige bevidsthed $\mathrm{mm}$. Refleksioner, der holdes sammen af én gen- 